\title{
Reduction in blood platelet size with increase in circulating numbers in the postoperative period and a comparison of the glass bead and rotating bulb methods for detecting changes in function
}

\author{
J. B. ENTICKNAP, T. S. LANSLEY, AND THELMA DAVIS \\ From the East Ham Memorial Hospital, London
}

SYNOPSIS The changes in blood platelet numbers, size, adhesiveness, and response to aden $\vec{z}$ sine diphosphate have been followed for about a month after major operations performed of 19 patients.

The well established increase in numbers was confirmed and reached a maximum of rathe्ध less than double the normal numbers in the third week. It was accompanied by a reduction of platelet size from $8 \cdot 3 \mu^{3}$ to $7 \cdot 2 \mu^{3}$, and by an increased responsiveness shown in all the tes employed. These abnormalities were preceded by an initial change in the reverse direction fro that obtaining at the peak of the response.

In this series the bead method proved superior, as a means of delineating the postoperati platelet response, to the rotating bulb method in tests of timing, proportional changes, and $\vec{f}$ discrimination.

A previous series of tests has shown that the platelets of patients with ischaemic heart disease were larger than those of the control subjects (Gooding and Enticknap, 1967a and b, and Enticknap, Gooding, Lansley, and Avis, 1969). Serial estimations following acute necrosis of the myocardiumshowed that, with recovery, these large platelets became progressively morenormal in size. This abnormality may be either a primary effect of the disease or secondary to the excessive deposition of thrombi causing the surviving platelets to be either younger or older than those in the controls. To elucidate this we have determined cell sizes in the postoperative period. At this time release of platelets into the circulation is known, predictably, to increase and it is reasonable to assume that this reduces the average age of the circulating cells. The results presented here show that these young cells are smaller. The opportunity was also taken to delineate other aspects of the postoperative response in order that those appropriate to testing of thrombolytic drugs could be recognized and to determine whether the glass

Received for publication 25 February 1969. bead method of Hellem (1960) or the rotati咅 bulb method modified from Payling-Wright (1941) was the more effective in detecting the response.

\section{Methods}

The methods have been fully described (Enticks nap et al, 1969) and only minor modification have been required in the four years that they have been in use. Platelets are now counted in the range 16-100 divisions (Coulter counter, mod B) but as there appears to have been a minor shifa in the calibration this still corresponds 3-17 $\mu^{3}$. The conversion factor determined each day instead of the mean figure over a period $\$$ now entered separately into each computer rum. The Hellem tubes were from a single batch made at one time and so have aged somewhat in the year of these experiments. The term 'platel size' refers to geometric mean volumes calculate in an IBM 1130 on a specially written programme. 


\begin{tabular}{|c|c|c|c|c|c|c|c|c|c|}
\hline \multirow{2}{*}{$\begin{array}{l}\text { Parameter } \\
\text { Measured }\end{array}$} & \multirow{2}{*}{$\begin{array}{l}\text { Preoperative } \\
\text { Period }\end{array}$} & \multicolumn{8}{|c|}{ Postoperative Period } \\
\hline & & $\begin{array}{l}\text { Days } \\
1-3\end{array}$ & $\begin{array}{l}\text { Days } \\
4-6\end{array}$ & $\begin{array}{l}\text { Days } \\
7-9\end{array}$ & $\begin{array}{l}\text { Days } \\
10-12\end{array}$ & $\begin{array}{l}\text { Days } \\
13-14\end{array}$ & $\begin{array}{l}\text { Third } \\
\text { Week }\end{array}$ & $\begin{array}{l}\text { Fourth } \\
\text { Week }\end{array}$ & $\begin{array}{l}\text { Fifth Week } \\
\text { and After }\end{array}$ \\
\hline $\begin{array}{l}\text { No. of tests } \\
\text { Total platelet } \\
\text { count } \times 10^{-3}\end{array}$ & $\begin{array}{l}24 \\
319 \cdot 9 \\
\end{array}$ & $\begin{array}{l}11 \\
308 \cdot 5 \pm 68 \cdot 0\end{array}$ & $\begin{array}{l}15 \\
287 \cdot 8\end{array}$ & $\stackrel{13}{358 \cdot 6 \pm 114 \cdot 9}$ & $\begin{array}{l}18 \\
409 \pm 146 \cdot 3\end{array}$ & $\stackrel{7}{443 \cdot 7} \pm 203 \cdot 7$ & $\begin{array}{l}10 \\
498 \cdot 1 \pm 178 \cdot 1\end{array}$ & $\begin{array}{l}5 \\
367 \cdot 4 \pm 104 \cdot 4\end{array}$ & $\stackrel{3}{383 \cdot 8} \pm 174 \cdot 1$ \\
\hline $\begin{array}{l}\text { Total platelet } \\
\text { size in } \mu^{3}\end{array}$ & $7 \cdot 735 \pm 0 \cdot 74$ & $8 \cdot 272 \pm 0 \cdot 53$ & $8 \cdot 141 \pm 0 \cdot 63$ & $7.938 \pm 0.75$ & $7 \cdot 636 \pm 0 \cdot 51$ & $7 \cdot 314 \pm 0 \cdot 55$ & $7 \cdot 217 \pm 0.67$ & $7 \cdot 440 \pm 0.92$ & $8 \cdot 247 \pm 0.40$ \\
\hline $\begin{array}{l}\text { Adhesive } \\
\text { platelet count } \\
\times 10^{-3} \text { bulb } \\
\text { method }\end{array}$ & $252 \cdot 7$ & $243 \cdot 3$ & $225 \cdot 0$ & 270.9 & $272 \cdot 6$ & $374 \cdot 3$ & $362 \cdot 3$ & 274.9 & $229 \cdot 8$ \\
\hline $\begin{array}{l}\text { Adhesive } \\
\text { platelet size in } \\
\mu^{3} \text { bulb method }\end{array}$ & $7 \cdot 735$ & $8 \cdot 262$ & 8.005 & $8 \cdot 155$ & $7 \cdot 783$ & $7 \cdot 293$ & $7 \cdot 25$ & $7 \cdot 29$ & $8 \cdot 23$ \\
\hline $\begin{array}{l}\text { Adhesive } \\
\text { platelet count } \\
\times 10^{-3} \text { bead } \\
\text { method }\end{array}$ & 177 & 168 & 197 & 206 & 195 & 229 & 275 & 169 & 251 \\
\hline $\begin{array}{l}\text { Adhesive } \\
\text { platelet size } \\
\text { in } \mu^{3} \text { bead } \\
\text { method }\end{array}$ & $7 \cdot 725$ & $8 \cdot 42$ & $8 \cdot 14$ & 8.02 & $8 \cdot 00$ & $7 \cdot 24$ & $7 \cdot 19$ & $7 \cdot 46$ & $8 \cdot 27$ \\
\hline $\begin{array}{l}\text { Ratio of } \\
\text { adhesive } \\
\text { counts by bulb } \\
\text { and bead } \\
\text { methods }\end{array}$ & $1 \cdot 68$ & $1 \cdot 46$ & $1 \cdot 20$ & $1 \cdot 35$ & $1 \cdot 42$ & 1.65 & 1.52 & $1 \cdot 43$ & $1 \cdot 17$ \\
\hline $\begin{array}{l}\text { ADP aggre- } \\
\text { gation } \\
\text { Percentage aggreg } \\
\text { in } 15^{\prime}\end{array}$ & $\begin{array}{l}70 \cdot 47 \\
\text { zated }\end{array}$ & $61 \cdot 01$ & $70 \cdot 83$ & $74 \cdot 30$ & $78 \cdot 61$ & 61.05 & $70 \cdot 39$ & 57.06 & $38 \cdot 03$ \\
\hline $\begin{array}{l}\text { Opacity change } \\
\qquad \frac{1 \mathrm{~cm}}{600} \times 10^{3}\end{array}$ & 27 & 20 & 24 & 25 & 27 & 28 & 30 & 21 & 17 \\
\hline $\begin{array}{l}\text { Opacity fall in } \\
1^{\prime} \\
\mathrm{dE} \frac{1 \mathrm{~cm}}{600} \times 10^{3}\end{array}$ & 12 & 7 & 8 & 9 & 13 & 14 & 13 & 8 & 6 \\
\hline $\begin{array}{l}\text { ADP-lag } \\
\text { (Secs) }\end{array}$ & $18 \pm 9 \cdot 8$ & $37 \pm 46 \cdot 1$ & $23 \pm 7 \cdot 9$ & $18 \pm 21 \cdot 7$ & $20 \pm 14 \cdot 0$ & $19 \pm 16 \cdot 5$ & $19 \pm 11 \cdot 0$ & $13 \pm 3 \cdot 5$ & $13 \pm 17 \cdot 0$ \\
\hline
\end{tabular}

Table Mean values and some standard deviations in measurements of platelet parameters

\section{Subjects}

The platelet responses to 19 major operations were studied. Two were splenectomies, one patient was treated with heroic doses of dipyridamole, and another had a platelet abnormality comparable to idiopathic thrombocytopenia. The remaining 10 men and five women were drawn from a wide unselected group. One to four preoperative tests were done and four to 10 postoperative tests, at clinically convenient times, to give a total of 106 tests. The average age of the subjects was $61 \cdot 6$ years $\pm 9,3$.

\section{Results}

The major findings are set out in the Table which shows the inverse relationship between numbers and size of platelets. There is remarkably close similarity between the changes in the counts of adhesive cells and of the total counts, and of the size measurements on both adhesive cells and their parent populations. The total response to adenosine diphosphate (ADP), the initial rate of response, and the percentage of cells responding all follow the pattern of the total cell count. but the delay (ADP lag time) in responding, after doubling in the first few days after operation, falls slowly again to normal. The reduction in mean platelet size is clearly progressive throughout the earlier part of the period. To test the significance of the change the value of the mean of the observations made in the first three days has been compared with the mean in the third week and the reduction is highly significant

( $t=3.873$ for 19 d.o.f.; $>0001 \mathrm{P}<0.01$ ).

Comparison of the two methods of measuring adhesiveness, referred to below as the bead (after Hellem) and bulb (after Payling-Wright) methods, shows significant differences. The bulb method when used in this series gave higher $\underset{\rightleftharpoons}{\rightleftharpoons}$ 
adhesive counts by an average ratio of 1.36 but this depended upon the rate of rotation or of pumping. The level can be set between about 10 and $90 \%$ adhesiveness at will by varying the rates. In the first few postoperative days a change, which is in a reverse direction to the major change, has been found in all parameters. This change itself reaches a peak in the third week. In the bulb method the reversal occurs in the second three-day period but the bead method shows it already in the first three days. This appears as a fall from 1.66 to 1.20 in the ratio between the two counts, which climbs again to 1.65 in the second week, indicating that the two tests delineate the change with equal effectiveness at the peak period although the bead method does so a little earlier. Another way of testing the efficacy of the two tests is to determine which gives an increase of, say, $30 \%$ over the preoperative level at an earlier stage. The bead method did so in seven cases at an average of 10 days, the bulb in two only though at an average of four days. In the rest of the cases the rise was on the same day. Similarly, the result from the bulb method increased by $30 \%$ earlier than did the total count on only two occasions and was later in five subjects, whereas the postbead adhesive count reached $1.3 \times$ the control value earlier in seven subjects and later only in one. Thus the bead method starts to respond earlier, reaches a reasonably certain increase earlier, and more often gives more information than the total count. But, can it always delineate the peak so clearly? Disregarding the cases in which no peak was seen in the period of study, in six of the other cases the simple total count gave a peak on the same test day as both methods, in six the bead method reached a peak earlier by an average of seven days, and in two of these the bulb method only gave its peak very late. Thus the bead method gives its peak earlier and more certainly. The mean peak times were for the total count $12 \cdot 1 \pm$ 2.2 days, for the bead method $10.8 \pm 3.8$ days, and for the bulb method $14.3 \pm 4.2$ days with average ratios of maximum count to preoperative average count of $1.68,1 \cdot 72$, and 1.78 respectively. Thus the only advantage of the bulb method is a higher proportional increase at the peak, but this is no more easily detectable by simple discriminatory tests. The degree of correlation between the percentage adhesiveness measured by bulb and bead methods was, however, significant

$$
(r=0.301 \pm 0.97:>0.001 \quad P<0.01) .
$$

Two young boys have been studied following splenectomy. They have not been included in the overall averages but the results of their tests were very similar to the general pattern. The cells decreased in size in one of them from $9.44 \mu^{3}$ to $9 \cdot 21 \mu^{3}$ while the count rose to 568,000 percmm and in the other from $9 \cdot 66 \mu^{3}$ to $8 \cdot 27 \mu^{3}$ during a change from 168,000 to 673,000 per $\mathrm{cmm}$.
The difference in size between adhesive ara non-adhesive cells was not marked in this serie and the average values for 108 measurements of $7 \cdot 75 \mu^{3}$ for all cells and $7 \cdot 89 \mu^{3}$ for adhesive ce were not significantly different. However, Table-I shows that these averages conceal a changizg relationship in which the adhesive cells tend to $b e$ larger at first and smaller at the time of minimum overall size. Thus the preoperative values are veiny similar at $7 \cdot 81 \mu^{3}$ for adhesive cells and $7 \cdot 74 \mu^{3} \mathrm{for}$ the whole population while those at the end of the second week are $7 \cdot 24 \mu^{3}$ and $7 \cdot 42 \mu^{3}$ respectivefy.

\section{Discussion}

It has long been known (Hueck, 1926) that the blood platelet count increases in the postoperative period and some other aspects of the respons have been recently reinvestigated. Emmons and Mitchell (1965) showed increased initial rate and maximum intensity of the ADP response. Ham and Slack (1967) demonstrated a fall in platefort count preceding the rise which was, however, accompanied by increased adhesiveness arad suggested that changes in function were establis $\mathbb{W}$ ed by the second day. Their series was carefuity selected to exclude complicated cases. Hampto and Mitchell (1966) showed that there was assêciated change in electrophoretic behaviour of platelets which was at a maximum on the firôt postoperative day. Recently Bennett (196) showed an increase in both total count and adhesiveness as early as four hours after operation and suggested that the latter is mediated by rest cell changes. This investigation is, however, the first of which we are aware in which the cell sige has been described and has demonstrated unequivocally a highly significant reduction the peak of the response. This can leave littie doubt that young platelets are smaller than oldêr ones and that senescence, unlike in many other cytopoietic lines, is associated with increasing size. In addition the initial change in so man parameters in a reverse direction to that seeva at the peak of the response has not been previously commented upon. Although it russ directly counter to the findings of Bennett (1968) it derives some support from the observations of Ham and Slack (1967).

The present comparison of the bulb and bean methods shows that the latter is the more suif able for detecting a postoperative response. I tests of timing, proportional changes, and di? crimination it proves superior to the bulb metho $\$$ It is only fair to comment that our usage does ne follow exactly that of the originator, but the major distinction between adhesion to a large mobile surface over many minutes and to close $B$ packed stationary beads for a few seconds, wi the attendant turbulence phenomena, in our vie leaves the comparison valid. It accords too with 
our previous finding that the bulb method gave no better discrimination between subjects with ischaemic heart disease and controls (Enticknap et al, 1969).

A possible explanation of our major finding, reduction in cell size with increasing peripheral blood platelet count in the postoperative period, may indeed lie in an inverse correlation between these two parameters, either of biological or methodological origin. In our previous large series many such correlations were examined, both between plasma counts and blood counts and the six parameters of platelet size that were then studied. As there existed in those series a reasonable degree of correlation in the subjects with ischaemic heart disease and in the controls, in whom there were no major changes in the blood counts, and no clear-cut differences between the closeness of the correlations in diseased and control subjects, this appears to be a fundamental relationship. However, in postoperative subjects, many of whom had some degree of arteriosclerosis by virtue of age, the degree of inverse change is much greater than could be explained by the loose correlation previously seen. This cannot therefore be the whole of the explanation and the decrease in cell size must be real and related to a changed platelet economy.

In the same investigation we demonstrated that adhesive cells were significantly smaller than nonadhesive cells. In control subjects the difference was $0.54 \mu^{3}$. In this series we have not calculated the size of non-adhesive platelets so the only comparative figure available is the smaller difference between total and adhesive populations of $-0 \cdot 14 \mu^{3}$, which in the previous series was $+0 \cdot 16 \mu^{3}$. However, while the preoperative difference was minute $\left(-0.07 \mu^{3}\right)$, by the end of the second week, when a large number of new small cells had been produced with a higher proportion than normal of adhesive cells, there was a normal difference of $+0 \cdot 18 \mu^{3}$. Thus the most likely explanation of the data is that both adhesive cells and new cells are in fact smaller than the average size, though the differences between them are slight; and further, that the two changes tend to be associated, the adhesive cells being the younger ones. This conclusion, based on size data, accords with that to be drawn from the higher proportion of the increased postoperative platelet count which is in the earlier stages (of newer cells) made up of more adhesive cells. The subsequent increase in cell size is yet further support for this interpretation. Hirsh, McBride, and Wright (1966) concluded that the bulb and bead methods measured substantially the same aspect of platelet function. However, their data contained various forms of both animal and human material and the propriety of calculating a single correlation based on such diverse data is arguable. The correlation they showed was largely due to the very low values derived from manipulated rabbit plasma; the closely related normal figures in man would not have revealed it. In our own previous comparison we found a correlation coefficient of $r=0.17$ between percentage adhesiveness measured by the two methods, which was only just significant at $\mathrm{p}<0.05$. In this investigation the correlation was better but again low, although now spread over a much wider range of activity. Though it may well be that the methods do measure the same aspect of platelet function (presumably the ability of glass surfaces to activate an adenosine triphosphate system) this investigation has clearly demonstrated the greater efficiency of the bead method in the postoperative situation.

We wish to acknowledge with grateful thanks the continuing financial support of the North Eastern Metropolitan Regional Hospital Board Research Committee and of Pfizer Limited of Sandwich, Kent.

\section{References}

Bennett, P. N. (1968). Role of erythrocytes in the acute platelet response to operation. J. clin. Path., 21, 695-697.

Emmons, P. R., and Mitchell, J. R. A. (1965). Post operative changes in platelet-clumping activity. Lancet, 1, 71-75.

Enticknap, J. B., Gooding, P. G., Lansley, T. S., and Avis, P. R. D. (1969). J. Atheroscler. Res., 10, 41-49.

Hellem, A. J. (1960). The present method for determination of platelet adhesiveness. Scand. J. clin. Lab. Invest., 12, suppl. 51

Ham, J. M., and Slack, W. W. (1967). Platelet adhesiveness after operation. Brit. J. Surg., 54, 385-389.

Hampton, J. R., and Mitchell, J. R. A. (1966). Abnormalities in platelet behaviour in acute illnesses. Brit. med. J., 1, 10781080.

Hirsch, J., McBride, J. A., and Wright, H. P. (1966). Platelet adhesiveness: a comparison of the rotating bulb and glassbead column methods. Thrombos. Diathes. haemorrh. (Stuttg.), 16, 100

Hueck, H. (1926). Blutplättchenveränderungen nach Operationen. Münch. med. Wschr., 73, 173.

Gooding, P. G., and Enticknap, J. B. (1967a). Platelet size and behaviour. Path. et. Microbiol. (Basel), 30, 665-70.

Gooding, P. G., and Enticknap, J. B. (1967b). Platelet volumes in patients with ischaemic heart disease, and in controls. J. Atheroscler. Res., 7, 711-713.

Payling-Wright, H. (1941). The adhesiveness of blood platelets in normal subjects with varying concentrations of anti. coagulants. J. Path. Bact., 53, 255-262. 